International

Medical Society

http://imedicalsociety.org

\title{
Analysis of the Action Strategies of the Brazilian National Health Policy of the Elderly from the Perspective of Nurses

\begin{abstract}
Sofia de Moraes Arnaldo1,5, Luiz Carlos de Abreu², Antônio YgorModesto de Oliveira1,5, Juvina Auana de Sousa Delfino 1,5, Ana Caryne Xenofonte Matias1,5, Maria Amanda da Silva1,5, Wallingson Michael Gonçalves Pereira1,5, Andréa Couto Feitosa ${ }^{1,5}$, Fernando Rocha Oliveira ${ }^{2,3}$, Italla Maria Pinheiro Bezerra², Luiz Vinicius de Alcantara Sousa 2,4, Francisco Winter dos Santos Figueiredo ${ }^{2,4}$, Fernando Adami ${ }^{2,4}$,Edige Felipe de Sousa Santos 1,2,3,5
\end{abstract}

\section{Abstract}

Introduction: Increase of the elderly population, which is a characteristic of developed countries, also occurs in developing countries in a fastest way. Changes in the demographic profile reflect changes in the epidemiological profile of the population, and they require the applicability of public policies such as the Brazilian National Health Policy of the Elderly, which enable the priority for structuration of services and programs encompassing emergent demands.

Objective: Analyze the action strategies of the Brazilian National Health Policy of the Elderly from the perspective of nurses.

Methods: This is a cross-sectional study of quantitative and qualitative approaches, performed with nurses from the teams of the Family Health Strategy (FHS), situated in the urban area of the city of Juazeiro do Norte, Ceara, Brazil, from March to April of 2015. Variables of both nurses (sex, age, time of professional formation, and time of experience) and dichotomous (developed strategies in the teams) were extracted from the questionnaire for Evaluation of Quality Improvement of the Family Health Strategy, modified from the SelfAssessment Notebooks 4 and 5, regarding the health of the elderly in session II, from the Brazilian Ministry of Health. Data were presented in tables as speeches and as absolute and relative frequency.

Results: From the 16 nurses, 87.5\% developed health promotion actions; $75 \%$ promoted educational activities addressing the statute
1 Centro Universitário Dr. Leão Sampaio. Juazeiro do Norte, CE, Brasil.

2 Laboratório de Delineamento de Estudos e Escrita Científica. Departamento de Ciência Básicas. Faculdade de Medicina do ABC, SP, Brasil.

3 Faculdade de Saúde Pública da Universidade de São Paulo. São Paulo, Brasil

4 Laboratório de Epidemiologia e Análise Estatística. Departamento de Saúde Coletiva. Faculdade de Medicina do ABC, Santo André, SP, Brazil.

5 Grupo de Pesquisa Epidemiologia das Doenças Crônicas Não Transmissíveis \& Grupo de Pesquisa Envelhecimento e Saúde Coletiva (GPESC). Centro Universitário Dr. Leão Sampaio. Juazeiro do Norte, CE, Brasil.

Contact information:

Fernando Rocha Oliveira.

झ oliveira.rocha.fernando@gmail.com 
of the elderly; $62.5 \%$ kept the registry of the elderly updated; $93.7 \%$ have ensured that $80 \%$ or more of their elderly patients were with updated vaccination; $81.3 \%$ and $68.8 \%$ answered that the oral examination and monitoring of oral health, respectively, are not established as routine activities. $75 \%$ did not conduct the examination of the body surface as a routine work; $75 \%$ said they promoted training for family caregivers, and $68.7 \%$ did not perform interventions for early detection of dementia. Although they pointed having performed health-promoting practices, when they described the performed and discussed actions with the elderly people, they were limited to medication delivery, to preferences in access to health care services, and to the rights of the elderly.

Conclusion: Most of the actions performed by nurses are linked to immunization and training educational activities. However, practices restricted to the transmission of information about specific policy issues and actions of curative nature have been identified, such as medication delivery, only. The applicability of the policy still represents a challenge regarding clinical interventions and maintenance of the updated registry of the elderly.

\section{Keywords}

Health of the Elderly; Public policies; Nursing.

\section{Introduction}

The Brazilian National Policy of Health for the Elderly (PNSPI) is an achievement derived from the emergent need of rapid population aging in the country that occurred in the last 60 years, ensuring improvements in health care provided to people over 60 years old.

Population aging has always happened, and it was intensified after the Industrial Revolution, where the inclusion of the technological mass was the starting point to innovations favorable to demographic transition. [1, 2] Other aspects favorable to the growth of the elderly population, such as changes in the patterns of survival and integration of women in the labor market, influenced the declines of mortality and fertility rates, respectively. [3, 4]

The population aging is best observed in developing countries, like in Brazil, where 650000 new el- derly are added per year, causing dynamism in morbidity and mortality patterns, as well as in supply and demand for tertiary health services, when the applicability of health policies in primary attention are unsatisfactory or inoperative. $[1,5]$ It is noteworthy that in $2007,72 \%$ of deaths were attributed to chronic non communicable diseases. [6]

It becomes a priority a reorganization of social health care molds in the process of aging, as well as changes in the provision of care whose purpose is the promotion, restoration and maintenance of the autonomy and independence of the elderly. [7]

The change of the demographic profile and new health care needs for the elderly require the adoption and fulfillment of public health policies, promulgating the structuring of services and programs that encompass the emergent demands of the new profile. [4] 
In this context, Brazil progresses, since the Constitution of 1988 with the creation of subsidies that guarantee social rights, autonomy, and participation of elderly people in society, then the Brazilian Ministry of Health issued a legal device to the health of the elderly by Ordinance No. 2,528, of October 19, 2006, promulgator of PNSPI, conferring the achievements of ensuring the right of the elderly concerning the life, culture, social assistance, education, housing, leisure, food, sport, transportation, among others, creating a healthy and active aging, fostered in the paradigm of functional capacity, with multidimensional approaches. [9, 10]

It is believed that the PNSPI is applied equally in different regions of Brazil by being a policy instituted by law that enables the performance of nurses in the health of the elderly in basic health care units to provide competent health assistance.

Thus, the objective is to analyze the action strategies of the Brazilian National Health Policy of the Elderly from the perspective of nurses.

\section{Methods}

Descriptive, cross-sectional study of quantitative and qualitative approaches, conducted in teams of the Family Health Strategy (FHS), situated in the urban area of the city of Juazeiro do Norte, located in the Metropolitan Region of Cariri in southern Ceara, Brazil, from March to April of 2015. This region has an area of $141 \mathrm{~km}^{2}$ and urbanization rate of $95.3 \%$, with a population of $249,939,000$ inhabitants, of which $14 \%$ are composed of people aged 60 years and more. [11, 12]

From the 56 family basic health care units of the urban area, teams were selected according to the proportion of elderly registered, which are 9-28\%, accounting for 48 teams allocated in the formula of the sample calculation for finite populations of cross-sectional studies [13], totaling 28 strategies as final sample.
The participants were 16 nurses who met the eligibility criteria: employment for at least six months in primary care in the city; work in teams with the highest proportion of elderly ascribed and located in the urban area of the municipality; agree to participate voluntarily after signing the free and informed consent term, as well as the post-informed consent term. The exclusion criteria were: temporary stoppage of services and transfer of the work team.

For the first phase of the study, it was used a questionnaire for Evaluation of Quality Improvement (EQI) of the Family Health Strategy. [7] The questionnaire was modified from the SelfAssessment Notebooks 4 and 5, from the Family Health Team, regarding the health of the elderly in session II, and from the Brazilian Ministry of Health, composed of 9 questions with dichotomous variables. The No. 4 notebook is aimed at professionals in the FHS, and it addresses global equities and the specific work processes, while the No. 5 notebook is directed to higher education professionals comprising health care activities and the results of coverage and impact.

The variables were: sex, age, time of professional formation, and time of experience of the interviewed nurses. The variables related to strategic actions proposed by the Brazilian National Health Policy of the Elderly developed by nurses from the teams of the Family Health Strategy, were categorized by quantitative dichotomy, by the application of the questionnaire.

Descriptive statistics was used and data were presented in tables in the form of absolute and relative frequencies as well as central tendency and dispersion measurements such as mean and standard deviation.

For the second phase of this research, which aimed to approach the reality of nurses and their practice, it was used a semi-structured interview guide, consisting of eight questions addressing the topic being studied. Data were organized by Minayo's content analysis technique. [14] 
The study followed the guidelines of the resolution 466/12, and it was approved by the Committee on Ethics of the Leao Sampaio College with protocol No. 43050415.2.0000.5048.

\section{Results}

The participants were 16 nurses from the urban area aged between 26 and 49 years, mean of 34 years $( \pm$ 7.09). Most, seven (44\%) were aged between 25 and 29, featuring a younger professional profile. Regarding the sex, 15 (94\%) were females. Concerning the time of professional formation, eight (50\%) of the interviewed had professional formation less than seven years, with a mean of 9.8 years $( \pm 6.11)$. Eight $(50 \%)$ of the participants presented time of experience at FHS less than six years (50\%), with a mean of 7.97 years $( \pm 6.43)$ (Table 1$)$.

Table 1. Characterization of the variables of the nurses from the Family Health Strategy teams of the urban area of Juazeiro do Norte - CE, Brazil. 2015.

\begin{tabular}{|l|c|c|}
\hline \multicolumn{1}{|c|}{ Variables } & N & $\%$ \\
\hline Sex & 15 & 94 \\
\hline Female & 1 & 6 \\
\hline Male & 16 & 100 \\
\hline Total & & \\
\hline Age (years) & 7 & 44 \\
\hline $25-29$ & 1 & 6 \\
\hline $30-34$ & 4 & 25 \\
\hline $35-39$ & 3 & 19 \\
\hline $40-44$ & 1 & 6 \\
\hline $45-49$ & 16 & 100 \\
\hline Total & 8 & \\
\hline Time of professional formation (years) & 50 \\
\hline$\leq 7$ & 3 & 19 \\
\hline $8-12$ & 3 & 19 \\
\hline $13-17$ & 1 & 6 \\
\hline $18-22$ & 1 & 6 \\
\hline$\geq 23$ & 16 & 100 \\
\hline Total
\end{tabular}

\begin{tabular}{|l|c|c|}
\multicolumn{1}{c|}{ Variables } & N & $\%$ \\
\hline Time of experience at FHS (years) & & \\
\hline$\leq 6$ & 8 & 50 \\
\hline $7-12$ & 4 & 25 \\
\hline $13-18$ & 3 & 19 \\
\hline $19-24$ & 1 & 6 \\
\hline Total & 16 & 100 \\
\hline
\end{tabular}

Table 2 depicts the quantification of frequency of elderly by teams, where there was variation in the proportion between 9 and 28\%, and it was possible to size the work of nurses with the amount of patients in teams.

Table 2. Distribution of elderly by sex in the teams of the Family Health Strategy of the urban area of Juazeiro do Norte - CE, Brazil. 2015.

\begin{tabular}{|l|c|c|c|c|}
\hline \multirow{2}{*}{ FHS } & \multicolumn{5}{|c|}{ Elderly } \\
\cline { 2 - 5 } & Male & Female & $\Sigma$ & $\%^{2}$ \\
\hline 1 & 220 & 321 & 541 & 14 \\
\hline 2 & 180 & 368 & 548 & 28 \\
\hline 3 & 154 & 243 & 397 & 10 \\
\hline 4 & 188 & 299 & 487 & 13 \\
\hline 5 & 253 & 415 & 668 & 15 \\
\hline 6 & 293 & 374 & 667 & 14 \\
\hline 7 & 231 & 339 & 570 & 15 \\
\hline 8 & 287 & 590 & 877 & 20 \\
\hline 9 & 279 & 494 & 773 & 22 \\
\hline 10 & 218 & 352 & 570 & 14 \\
\hline 11 & 348 & 606 & 954 & 21 \\
\hline 12 & 189 & 236 & 425 & 9 \\
\hline 13 & 350 & 616 & 966 & 19 \\
\hline 14 & 278 & 479 & 757 & 13 \\
\hline 15 & 301 & 528 & 829 & 20 \\
\hline 16 & 246 & 369 & 615 & 16 \\
\hline & & Source: Secretary of Health of Juazeiro do Norte, 2015 \\
\hline
\end{tabular}

Table 3 lists the frequency of responses of the developed strategic actions, where 87.5\% developed health promotion actions; 75\% promoted 
Table 3. Strategic actions developed in health care for the elderly in the teams from the Family Health Strategy of the urban area of Juazeiro do Norte - CE, Brazil. 2015.

\begin{tabular}{|l|c|c|}
\multicolumn{1}{c|}{ Açtions } & N & \%1 \\
\hline Socialization/ Health promotion/ Improvement in quality of life \\
\hline Yes & 14 & 87.5 \\
No & 2 & 12.5 \\
\hline Total & 16 & 100 \\
\hline
\end{tabular}

Educational approaches relating contents from the Statute of the Elderly

\begin{tabular}{|l|c|c|}
\hline Yes & 12 & 75 \\
\hline No & 4 & 25 \\
\hline Total & 16 & 100 \\
\hline
\end{tabular}

Updated registry of the elderly

\begin{tabular}{|l|c|c|}
\hline Yes & 10 & 62.5 \\
\hline No & 6 & 37.5 \\
\hline Total & 16 & 100 \\
\hline
\end{tabular}

$80 \%$ of the elderly with updated vaccination

\begin{tabular}{|l|c|c|}
\hline Yes & 15 & 93.7 \\
\hline No & 1 & 6.3 \\
\hline Total & 16 & 100 \\
\hline Oral routine examination & & \\
\hline Yes & 3 & 18.7 \\
\hline No & 13 & 81.3 \\
\hline Total & 16 & 100 \\
\hline
\end{tabular}

Systematic monitoring of oral health

\begin{tabular}{|l|c|c|}
\hline Yes & 5 & 31.2 \\
\hline No & 11 & 68.8 \\
\hline Total & 16 & 100 \\
\hline
\end{tabular}

Body surface routine examination

\begin{tabular}{|l|c|c|}
\hline Yes & 4 & 25 \\
\hline No & 12 & 75 \\
\hline Total & 16 & 100 \\
\hline
\end{tabular}

Training for family caregivers

\begin{tabular}{|l|c|c|}
\hline Yes & 12 & 75 \\
\hline No & 4 & 25 \\
\hline Total & 16 & 100 \\
\hline Early detection of dementia & & \\
\hline Yes & 5 & 31.3 \\
\hline No & 11 & 68.7 \\
\hline Total & 16 & 100 \\
\hline & 1: Absolute values and percentages \\
\hline
\end{tabular}

educational activities addressing the statute of the elderly; $62.5 \%$ kept the registry of the elderly updated; $93.7 \%$ have ensured that $80 \%$ or more of their elderly patients were with updated vaccination; $81.3 \%$ and $68.8 \%$ answered that the oral examination and monitoring of oral health, respectively, are not established as routine activities. $75 \%$ did not conduct the examination of the body surface as a routine work; $75 \%$ said they promoted training for family caregivers, and $68.7 \%$ did not perform interventions for early detection of dementia.

According to the testimonies of the nurses (Table 4), it was analyzed their perception about PSNPI. Therefore, as per data organization following the categorization process of the speeches, the built empirical category was: Policy Applicability: found evidences (Figure 1).

Table 4. Applicability of the Brazilian National Health Policy of the Elderly: found evidences. Testimonies of nurses from the city of Juazeiro do Norte, Ce, Brazil. 2015.

It's about the rights of the elderly, about the preference in medical care, about the medication delivery guaranteed [...]

The issue of care, the issue of rights, the right to medication, the right to medical consultation, the right as the elderly code orders

ENF11

I don't know it. Maybe I know it, but I can't talk about it

[...] The priorities of the elderly, the care be differentiated [...] regarding the home visit [...] for the prevention of maltreatment $[\ldots]$

[...] There is the issue of the rights of the elderly, the issue of having a caregiver [...] how about their health condition, if they're taking the medication correctly, if they're well fed, if they're being monitored by the community health agent [...]; there are programs about hypertension and diabetes targeted to them 
Figure 1: Categorization process of the speeches

\begin{tabular}{|c|c|c|c|}
\hline Registration Units & $\begin{array}{l}\text { - Right to medication } \\
\text { - Right to medical consultation } \\
\text { - Statute }\end{array}$ & $\begin{array}{l}\text { Empirical } \\
\text { Category }\end{array}$ & $\begin{array}{l}\text { Policy Applicability: } \\
\text { found evidences }\end{array}$ \\
\hline
\end{tabular}

\section{Discussion}

The teams of the Family Health Strategy are widespread in Brazil as an important strategy for the reorganization of health care, according to the principles and guidelines of the Brazilian Unified Health System (SUS). Some characteristics, which determine the specifications of each team acting in the sanitary area, are important to consider in order to obtain a comprehensive and better information about the health of the population. In this manner, the knowledge of the profile of nurses is necessary because they are members within the scope of professionals who work in these teams. [15]

In regard to the feminization of the health professionals who were interviewed in this research, the Federal Council of Nursing described the profile of Brazilian nursing because even though this field comes from a feminine sphere, there is an increase in the number of male professionals which gives a tendency to the masculinization of this health area. [16]

About the time of professional formation, it can be explained by the increasing deployment of nursing schools in the study area, where there are four institutions forming 200 to 300 nurses per semester, allowing an increase in the number of professionals launched. The time of professional formation can be indicative of relative maturity and time of experience of the nurse in the labor market. The baccalaureate degree reveals the competence and skill of the nurse, as well as the time of professional formation in a particular time reflects the knowledge and ability valued in a given period. [17]

To describe the applicability of the Brazilian National Health Policy of the Elderly identifying the main strategic actions, it was analyzed the relationship between time of professional formation and the time of experience in the FHS. It is believed that these variables influenced the outcomes of this study, considering the possibility of the professionals be seeking ways of qualifying their job skills throughout the years.

Regarding the proportion of elderly by family health team, a significant proportion was identified. This increase causes a change in the context of health care services offered by a city because the demands end up being differentiated, and they must contain relevant aspects to the target audience that needs care.

The study "Public policies for the elderly" showed that the improvement factors in the quality of health of the elderly, which were promoted after the structuring of PNSPI, were crucial to the reduction in mortality and to the increasing of the life expectancy, since this policy aims to create conditions to promote the extension of the life of the elderly by putting into practice actions for the elderly and for those who will grow old. [18]

It is noticed greater prevalence of females in the stratification of the number of elderly. The longevity of the female population explains the difference in the composition by sex, where the percentage of female elderly population is higher compared to the male population. [19] This longevity is attributed to the increased use of services (preventive or curative), demand for care assistance, lower risk of proportional mortality due to traffic accidents and homicides (external causes), and biological characteristics, providing greater survival and guaranteeing the feminization of the old age. $[3,20]$ 
It is perceived that most of the strategic actions are developed by nurses in the FHS teams of the urban area, while respecting the proposals recommended by the PNSPI. The actions referring to the development of collective strategies of socialization, promotion of health, and improvement of the quality of life for elderly, obtained as affirmative response $87.5 \%$ of the questionnaires, which conferred the development of actions in the workplace environment, the concern with the promotion of health, and the quality of life for elderly.

When the nurses were analyzed on the knowledge, appreciation, and development of educational activities with the elderly approaching contents related to the rights and to the Statute of the Elderly, it was found that $75 \%$ of nurses from the FHS performed such activity.

About the updating registry of the elderly ascribed in the area of the FHS, discriminated by sex, it was found that $62.5 \%$ of the units had updated registry, showing that most teams were aware of the number of elderly people in their area, but in $6(37.5 \%)$ this was not observed. The high rate of teams without an updated registry of the elderly reflected in unawareness of the real profile of the population that should receive differential care.

The mechanism of registration, supplying, and data analysis in the Brazilian Health Information Systems (SIS) represent attributes that should be performed by all of the professionals from the FHS, and these data represent an important tool for planning and evaluation of actions related to the health of the elderly, as well as for allocation of federal funds for the implementation and maintenance of health facilities. [7]

In relation to the update in vaccination, assessing whether $80 \%$ or more of the elderly in the local area are being vaccinated regularly, it was obtained 93.7\% of affirmative answers to such action, confirming the development of actions in the promotion of health involving primary care in accordance with the National Immunization Policy, as recommended by the PNSPI.
In our study scenario, it was identified a gap regarding the training activity for the health professionals. PNSPI establishes a guideline that enables the training of human resources involved in the care assistance to the elderly, counting on the involvement of all government agencies, health care institutions, educational training institutions, and society itself in its practical effectiveness.

When they were evaluated about oral routine examination in the care service, and about the systematic monitoring of oral health, it was found that this exam is not performed in most of the elderly $(81.3 \%)$ of the FHS, as well as in about $70 \%$ of the health care units there is not a systematic monitoring of oral health of the elderly, demonstrating that these activities, in most cases, are not performed.

The World Health Organization (WHO) established in the active aging book a health policy about the continuity of care with the oral health, especially for identification of caries, periodontal disease, tooth loss and, oral cancer in order to prevent problems that generate financial burden to individuals and society that could reduce self-confidence and quality of life. [17]

Regarding the body surface routine examination of the elderly, it was found that in $75 \%$ of health care units this examination is not routine.

The evaluation of the body surface examination of the elderly as a routine established in the service has great importance with regard to the promotion of health and to disease prevention. Thus, it is necessary the adequacy of the FHS to monitoring and screening in the health care of the elderly.7 Simple exams being placed as routine in the systematic actions performed by nurses in the FHS, may favor the quality of health of individuals, avoiding the appearance and delaying possible costly diseases.

When evaluating the development of intervention with the families of the elderly, with the completion of training for family caregivers, it was obtained $75 \%$ of positive responses, showing the concern of professionals with the elderly care in the home environment. 
Regarding the development of appropriate interventions in the elderly population for early detection of dementia, $68.7 \%$ of negative responses were obtained as a result. The complexity of diagnosis of neuropsychological disorders such as dementia and depression in elderly people is due to the specificity of instruments and tests used to assess the cognitive state, so the difficulty and low early detection of dementia by the health professionals may be common in basic health services [21]. The provision of information and training on how to care for those who are aging to family members and to other caregivers, is consistent with the formalities of PNSPI, since it this dictates that once known the fragile condition of the elderly person, it is necessary the inclusion of the family caregiver as a partner of the care team, subsequently evaluating their actions. [22]

The integration of the elderly person in different environmental contexts has influence in the development of the care, leaving the professionals to the need to adapt the care to a global, interdisciplinary and multidisciplinary approach. The specificity of the elderly requires the use of flexible techniques that can be adaptable to their needs, which are constantly changing, characterizing the need for a holistic assessment guided by the identification and recognition of their priorities, in order to ensure the prevention and detection of aggravations. [23]

In this way, interventions should be carried out aiming to promote the autonomy and independence of the elderly, stimulating them for self-care. [24]

It is important to point out that PNSPI is not the same as the Statute of the Elderly. There is confusion regarding both documents

Before the exposure of speeches, it was perceived that most of the nurses knew the policy, but they did not show significant knowledge about their guidelines, about promotion of health and disease prevention, and about what is really recommended and established as priorities in the health care of the elderly, stating empirical knowledge about the thematic. Conversely, six (37\%) said they did not have any knowledge about PNSPI and also that they had never heard about it.

However, getting closer to reality, the testimony revealed that the applicability of the policy was limited to bureaucratic actions, as related to medication delivery, exposing the predominance of the curative model across the health promotion. It was also seen a restriction of words in relation to the content because the nurses were limited to specific information without prioritizing the construction of knowledge, failing to adequately describe the benefits and actions developed, restricting themselves to the basics aspects known through their experiences in life and at work.

In this understanding, it is possible to see negligence by the professionals in search for information, new knowledge, and new health care modalities that allow for an attention with more quality to the users, creating a conception that knowledge they learned is enough to provide care.

Thus, with respect to this emphasis, the preventivist practices, some aspects may be associated with this conception of the professionals, where be highlighted the professional training and organization of health services.

Professional formation is questioned although the discussions are about the need for a focused action in order to meet the principles and guidelines of the SUS. Actions and changes movements are still incipient and they are often unrelated to these principles. [25]

This reality found in the study is a reflex in the possible traditional model of professional formation, which is guided by biological agents, focusing on the disease and, the subject affected by the disease ends up disregarded and decontextualized from the health/disease process [25].

In this context, studies reveal that the preparation of professionals to work at different levels of the health system, especially in primary care, is the cha- 
llenge of the educational training institutions mainly because such training should be in line with the current healthcare system in the country, with the team work, and with integral attention to health care, as recommended by the curricular guidelines. [26]

For this purpose, aiming to overcome this challenge, curricula aimed at the development of required competences for working in the health area of the SUS should provide educational opportunities to ensure to the nursing students the implementation of the theoretical knowledge and the development of political and relational skills that have as objective the promotion of health, and not only technical skills. [27]

The changes mean the breakage of old paradigms, highlighting characteristics of the biomedical model, still very impregnated in the practice of health professionals. Nonetheless, these changes involve people, values, cultures, and specifically in health and education fields, they also involve ideological, social, economic, and historical issues. [27]

The focus still being predominantly biologicist, curative, medical-centered and disarticulated from the practices in health may be the reflex of the professional formation, which reveals the unpreparedness of the professionals to work in the perspective of promotion of health. In this sense, the professional formation should be subsidized by the empowerment, intersectioriality, equity, popular participation, and autonomy concepts that will provide the incorporation on the part of the professionals of the promotion of health in their practices. [27]

Training activities are valid, considering the figure of the nurse as a key element of the health team that interacts longer with the user. It is fundamentally important that the role of the nurse is properly developed.

Nursing should invest in the preparation of people who can competently identify the main problems in the elderly population; discuss the actions to be implemented; systematize these actions; and sort the practices in health from prior knowledge about health policies. [28]

The effectiveness of a public policy requires the conscious, ethics, and citizen attitude of the related people. The state, health professionals, the elderly individual, and society in general are responsible for this process. [24] The challenge is in the ethical awareness of everyone involve and in the search for a society prepared to act against the possible difficulties that the new demographic status demands.

Knowing the policy is significant to ensure a qualified and differentiated health care service based on the principles and guidelines governing the same. Supporting health care, considering the elderly population and being provided with predetermined strategies through previous performed studies, it can be seen autonomy in the development of sanitary actions. Therefore, the challenge is to overcome the rapid growth of the elderly population by providing better health conditions suitable to the environment in which they are immersed.

Thus, investing in the development of health promotion actions within groups and in activities in the community to guarantee improvements in the quality of life of the elderly, may represent new perspective for themselves and reduction of expenditure because activities of this nature do not require much financial effort.

PNSPI mentions in its guidelines that the health professionals involved in caring for the elderly should know about their rights, making them agents of the actions of their lives in society.

It is noticed that most of the questioned actions are developed largely by graduated nurses from the teams of the family health strategy, qualifying the care provided to the elderly person as recommended by the Brazilian National Health Policy of the Elderly. It is noteworthy that those negativities found must be assessed and adapted to the policy models in order to ensure effective assistance to the population over the age of 60 . 
The aim of this study was not to identify factors associated with the applicability of the Brazilian National Health Policy of the Elderly, but it was sought to identify which of the main health actions implemented by PNSPI were developed in this study scenario. Thus, it is important to think over the data obtained through interviews, which may not correspond to reality. Population-based studies represent data closer to reality than those based on convenience sample.

\section{Conclusion}

Most of the actions performed by nurses are linked to immunization and training educational activities. However, practices restricted to the transmission of information about specific policy issues and actions of curative nature have been identified, such as medication delivery, only. The applicability of the policy still represents a challenge regarding clinical interventions and maintenance of the updated registry of the elderly.

\section{References}

1. Vasconcelos AMN, Gomes MMF. Transição Demográfica: a experiência brasileira. Rev. Epidemiol. Serv. Saúde. 2012 Dez; 21(4): 539-548.

2. Minayo MCS. O envelhecimento da população brasileira e os desafios para o setor saúde. Cad. Saúde Pública. 2012 Fev; 28(2): 208-209.

3. Tibulo C, Carli V, Dullius AIS. Evolução populacional do Brasil: uma visão demográfica. Revista Scientia Plena. 2012 Jan-Abr; 8(4).

4. Mendes ACG et al. Assistência pública de saúde no contexto da transição demográfica brasileira: exigências atuais e futuras. Cad. Saúde Pública. 2012 Mai; 28(5): 955-964.

5. Brasil MS. Estatuto do Idoso. 3 ed. Brasília: Ministério da Saúde; 2012.

6. Schmidt MI, Duncan BB, Silva GA, MenezesAM, Monteiro CA, Barreto SM, Chor D, Menezes PR. Doenças crônicas não transmissíveis no Brasil: carga e desafios atuais. The Lancet: série saúde no Brasil. 2011 Mai;1(1): 61-74.
7. Luz LA, Futino MI, Luz EA, Martins GM, Barbosa EPM, Rocha LM. Avaliação das ações estratégicas na atenção à saúde do idoso em Unidades Básicas de Saúde de Teresina-PI. Revista Brasileira de Medicina de Família e Comunidade. 2012 Jan-Mar; 7(22): 20-26.

8. Secchi L. Políticas Públicas: Conceitos, Esquemas de Análise, Casos Práticos. 2010; 496p.

9. Oliveira RCS, Scortegagna PA, Oliveira FS. Trajetórias históricas das políticas públicas para a educação na terceira idade. Biblioteca Virtual da UNICAMP. 2012.

10. Gontijo EEL, Inocente NJ, Kamimura QP. Políticas públicas voltadas ao Idoso do Brasil. Anais do XV Encontro Latino Americano de Iniciação Científica, XI Encontro Latino Americano de Pós-Graduação e do $V$ Encontro Latino Americano de Iniciação Científica Júnior. 2011.

11. Juazeiro do Norte,Prefeitura Municipal.Dados Gerais da Cidade. 2014.

12. SIAB,Sistema de Informação da Atenção Básica. Indicadores. 2014.

13. Lopes MOO. Desenhos de Pesquisa em Epidemiologia. In: Rouquayrol MZ, Silva MGC. Epidemiologia \& Saúde. 2013; 7ed: 121-150.

14. Gomes R. A análise de dados em pesquisa qualitativa. In: Minayo, MCS (org). Pesquisa Social: teoria, método e criatividade. 1999; 14ed: 67-79.

15. Cotta RMM, Schott M, Azeredo CM, Franceschini SCC, Priore SE, Dias G. Organização do trabalho e perfil dos profissionais do Programa Saúde da Família: um desafio na reestruturação da atenção básica em saúde. Rev. Epidemiologia e Serviços de Saúde. 2006; 15(3): 7-18.

16. COFEN, Conselho Federal de Enfermagem. Perfil da enfermagem brasileira. 2015.

17. Martins C, Kobayashi RM, Ayoub AC, Leite MMJ. Perfil do enfermeiro e necessidades de desenvolvimento de competência profissional. Rev. Texto e Contexto Enferm. 2006 Jul-Set; 15(3): 472-478.

18. Rocha IF. Políticas públicas para a terceira idade: uma análise sobre a política nacional do idoso no Brasil. Trabalho de Conclusão de Curso apresentado ao curso de Especialização em Gestão da Organização Pública da Universidade Estadual da Paraíba. 2014.

19. Camarano AA. Envelhecimento da população Brasileira: uma contribuição Demográfica. IPEA.2002 Jan; 31p. 
20. Camarano AA. Os Novos Idosos Brasileiros: Muito Além dos 60?IPEA. 2004 Set; 604p.

21. Schlindwein-Zanini R. Demência no idoso: aspectos neuropsicológicos. Revista Neuroc. 2010 Jan-Fev; 18(2):220-226.

22. WHO. World Health Oganization. Envelhecimento ativo: uma política de saúde. Organização Pan-Americana da Saúde. 2005.

23. Brasil MS. Portaria $n^{\circ} 2528$, de 19 de outubro de 2006. Política Nacional de Saúde da Pessoa Idosa. Brasília: Ministério da Saúde; 2006.

24. Martins JJ, Albuquerque GL, Nascimento ERP, Barra DCC, Souza WGA, Pacheco WNS. Necessidades de educação em saúde dos cuidadores de pessoas idosas no domicílio. Revista Texto e Contexto Enferm. 2007 Abr-Jun; 16(2):254-262.

25. Oliveira IC, Balard CR, Cutolo LRA. Formação profissional em saúde: integralidade em perspectiva. Revista Sau. \& Transf. Soc. 2013 Jan; 4(1):69-72.

26. Maranhão EA, Almeida M. A construção coletiva das diretrizes curriculares nacionais dos cursos de graduação da saúde: uma contribuição para o Sistema Único de Saúde. Diretrizes curriculares nacionais para os cursos universitários da área da saúde. 2003.

27. Chiesa $A M$ et al. A formação de profissionais da saúde: aprendizagem significativa à luz da promoção da saúde. Revista Cogitare enferm. 2007; 12(2):236-40.

28. Bezerra IMP, Sorpreso ICE. Concepts and movements in health promotion to guide educational practices. Journal of Human Growth and Development. 2016; 26(1):11-20.

Publish in International Archives of Medicine

International Archives of Medicine is an open access journal publishing articles encompassing all aspects of medical science and clinical practice. IAM is considered a megajournal with independent sections on all areas of medicine. IAM is a really international journal with authors and board members from all around the world. The journal is widely indexed and classified Q1 in category Medicine. 